\title{
Feelings of pleasure of nurses working in primary care
}

\author{
Sentimentos de prazer no trabalho das enfermeiras na atenção básica \\ Sentimientos de placer de las enfermeras que trabajan en la atención primaria
}

Grizielle Sandrine de Araujo Rocha'

ORCID: 0000-0001-7767-0748

Maria Sandra de Andrade"

ORCID: 0000-0002-9551-528X

Darine Marie Rodrigues da Silva"

ORCID: 0000-0001-9111-6380

Marlene Gomes Terra"'I

ORCID: 0000-0001-9402-561X

Sílvia Elizabeth Gomes de Medeiros"

ORCID: 0000-0002-8118-0757

Jael Maria de Aquino"

ORCID: 0000-0001-5095-1662

\section{ABSTRACT}

Objective: identify the sources that generate feelings of pleasure at work in the perception of primary care nurses. Methods: this is a descriptive study with a qualitative approach, developed with eleven nurses working in Primary Health Care Units. Data were collected using semi-structured interviews, systematized and analyzed using Bardin's content analysis technique and based on the theoretical framework of Psychodynamics of Work. Results: pleasure at work was related to the resolubility of the nurse's work, interpersonal relationship with the team, therapeutic relationship with the community, positive professional return, identification with work in nursing and public health. Final considerations: The factors that generate feelings of pleasure may contribute to guide actions that value the optimization of the nurses' work and, consequently, the care provided to the primary care user.

Descriptors: Pleasure; Mental Health; Primary Health Care; Occupational Health; Nursing.

\section{RESUMO}

Objetivo: Identificar as fontes geradoras de sentimentos de prazer no trabalho na percepção de enfermeiras da atenção básica. Métodos: Trata-se de um estudo descritivo com abordagem qualitativa, desenvolvido com onze enfermeiras atuantes em Unidades Básicas de Saúde. Os dados foram coletados por meio de entrevistas semiestruturadas, sistematizados e analisados utilizando-se a técnica de análise de conteúdo de Bardin e fundamentada no referencial teórico da Psicodinâmica do Trabalho. Resultados: O prazer no trabalho foi relacionado à resolutividade do trabalho do enfermeiro, relacionamento interpessoal com a equipe, relacionamento terapêutico com a comunidade, retorno profissional positivo, identificação com o trabalho na enfermagem e na saúde pública. Considerações finais: Os fatores geradores de sentimentos de prazer podem contribuir para orientar ações que prezem pela otimização do trabalho dos enfermeiros e, por conseguinte, do cuidado prestado ao usuário do serviço da atenção básica.

Descritores: Prazer; Saúde Mental; Atenção Primária à Saúde; Saúde do Trabalhador; Enfermagem.

How to cite this article:

Rocha GSA, Andrade MS, Silva DMR, Terra MG,

Medeiros SEG, Aquino JM. Feelings of pleasure of nurses working in primary care. Rev Bras Enferm. 2019;72(4):1036-43. doi: http://dx.doi.org/10.1590/0034-7167-2018-0518

Corresponding Author:

Grizielle Sandrine de Araujo Rocha

E-mail: grizrocha@hotmail.com

Submission: 06-18-2018

Approval: $10-14-2018$

\section{RESUMEN}

Objetivo: identificar las fuentes que generan sensaciones de placer en el trabajo en la percepción del personal de enfermería de atención primaria. Método: se trata de un estudio descriptivo con un abordaje cualitativo, desarrollado con once enfermeras que trabajan en las Unidades de Atención Primaria de Salud. Los datos se recogieron mediante entrevistas semiestructuradas, se sistematizaron y analizaron utilizando la técnica de análisis de contenido de Bardin y se basaron en el marco teórico de la Psicodinámica del Trabajo. Resultados: el placer en el trabajo estaba relacionado con la resolución del trabajo de la enfermera, la relación interpersonal con el equipo, la relación terapéutica con la comunidad el retorno profesional positivo, la identificación con el trabajo en la enfermería y en la salud pública. Consideraciones finales: los factores que generan sensaciones de placer pueden contribuir a orientar acciones que valoren la optimización del trabajo de las enfermeras y, en consecuencia, la atención al usuario de la atención primaria.

Descriptores: Placer; Salud Mental; Atención Primaria de Salud; Salud Laboral; Enfermaría. 


\section{INTRODUCTION}

The Primary Care (PC) was structured to be the main gateway for the user to enter the Brazilian Unified Health System (SUS), besides acting as a communication center of the Health Care Network (Rede de Atenção à Saúde-RAS). The Basic Health Units (UBS) should provide primary care to the affiliated population of a region and thus fulfill the essential role in ensuring accessibility and good health care ${ }^{(1)}$.

The nurse's work in the UBS should be to manage the nursing team, receive the users, do actions of primary care, monitoring in health and reference and counter reference of the users in the RAS. In this perspective, nurses should exercise care by listening, respecting, humanizing, and establishing dialogue in interpersonal relationships. These actions require psychological equilibrium and skills of the professional to meet the users and coordinate a team. It is also in primary care that the nurse handles with the reality of poor communities, few resources in the face of the demands and demands of the work ${ }^{(2-3)}$.

The work should provide pleasure for those who practice it, because it should bring personal and professional achievement. According to the theory of Psychodynamics of Work, developed by the French psychoanalyst Christophe Dejours, we understand the dynamics of pleasure in work as part of mental health and, in order to obtain this sensation, it is important that the organization of work allow the worker to exercise and enhance his psychosensory, psychomotor and psychic abilities. Therefore, people who works with pleasure will present a greater positivity related to life in general and, consequently, offer a better service to users ${ }^{(4)}$.

Worker has the experience of a healthy work when is possible to manage pressures and charges, even though the work environment promotes psychological instability. However, when the worker is unable to maintain the equilibrium and escapes from the suffering, ends up turning it into pathogenic suffering and is affected. This situation has repercussions on the worker's health, in general, and on nursing, in particular ${ }^{(5)}$.

Moreover, when the organization of work allows workers to develop their productive potential, exercise their skills and creativity, and provide people with cultural, social, political and technical development, bringing with it personal and professional achievement, is possible to say that work generates experiences of pleasure ${ }^{(6)}$.

When considering the dialectical process in the dynamics of work, we observe that nurses face situations that may bring experiences of pleasure and/or suffering, depending on the way they deal with these situations.

Experiencing pleasure at work is possible when the professional is able to mobilize himself to change the situation that causes discomfort and conflict and face adversity. Identifying the feelings of pleasure at work can contribute to create a space favorable to physical and mental health, a healthy work environment and a better quality of services provided, avoiding pathogenic suffering in this category, whose job is to take care. Based on this, we start with the question: which reasons pointed out by nurses working in the PC generate pleasure in their work?

\section{OBJECTIVE}

To identify the sources that generate feelings of pleasure at work in the perception of nurses of PC.

\section{METHODS}

\section{Ethical aspects}

This study followed Resolution 466 of December 12, 2012, which guides the research conducted with human beings, and the project was approved by the Comitê de Ética e Pesquisa do Complexo Hospitalar Hospital Universitário Oswaldo Cruz (Ethics and Research Committee of the Oswaldo Cruz University Hospital Complex HUOC)/ Pronto-Socorro Cardiológico Universitário de Pernambuco (University Emergency Cardiology Center of Pernambuco - Procape). All participants were informed about the research and signed the Informed Consent Form. To ensure confidentiality and anonymity, the names of the research participants were expressed by N1 to N11 according to the order of the interviews.

\section{Theoretical-methodological reference}

Data analysis was based on the theoretical referential of Work Psychodynamics recommended by Chistophe Dejours ${ }^{(6)}$.

\section{Scenario and type of study}

This is a descriptive research with qualitative approach, developed in Basic Health Units (UBS) located in Sanitary District VII in Recife, Pernambuco. This study presents an excerpt from the master's thesis entitled Prazer e sofrimento do enfermeiro da atenção básica à luz da Psicodinâmica do Trabalho (Pleasure and suffering of primary care nurses in the light of Work Psychodynamics).

\section{Methodological procedures}

Nurses working in the Basic Health Units (UBS) participated in the study, regardless of age, gender and length of service. Nurses who had been working at the PC for less than one year or who were unable to participate in the study during the data collection period were excluded from the study. The criterion for selecting the sample was convenience, and, in contact with each participant, the research objective and the conditions of participation were detailed. The sample size was defined by data saturation.

Data were collected through a semi-structured interview, with closed questions aimed at characterizing the sample and open questions to verify the feelings of nurses related to work.

We asked to the participants of the survey to answer the closed questions and then began the interview that was recorded and had an average duration of 40 minutes. Data collection was done by one of the researchers, with previous scheduling with the professional who chose the best day and time for the interviews. The data collection period occurred in April and August, 2015. There were no refusals of participation in the study.

\section{Data analysis}

We used descriptive analysis for the analysis of sociodemographic data. We did the transcription of the speeches for the qualitative analysis and examined this material using the content analysis technique proposed by Bardin ${ }^{(7)}$. The stages of the analysis consisted of pre-analysis, material exploration, treatment 
of results, inference and interpretation. Thus, we did exhaustive readings of the transcribed interviews, as well as data coding in order to make them representative, in addition to the choice of units, the enumeration and selection of categories ${ }^{(7)}$.

Thus, considering the regularity of the discourse and the units of meaning, we identified the following categories: (1) Resolubility of the nurse's work; (2) Interpersonal relationship with the team; (3) Therapeutic relationship with the community; (4) Identification/ Achievement of the nurse working in the area of nursing and public health; and (5) Positive professional return. In the last category, the following subcategories were identified: Financial remuneration, Recognition of the work of nurses in PC and Autonomy of nurses in PC.

\section{RESULTS}

The study sample consisted of 11 nurses, with a mean age between 40 and 72 years, with a variation between 31 and 50 years. The average monthly income was $R \$ 6.945,00$, the lowest was $R \$ 4.000,00$ and the highest $R \$ 10.000,00$. The average time of professional performance of the sample was 16.5 years, with a variation between 8 and 27 years. The average time that they work at PC was 13.8 years, with variation between 6 and 23 years, and this last data is representative of the time of performance in public service. Therefore, it is important to emphasize that the process of entering to work at PC of all of them was by a public tender. The declared working day was 40 hours per week, 5 of them in exclusive dedication and 6 had another employment relationship.

The contents related was grouped in experiences of pleasure, satisfaction, joy and well-being in the workplace based on the categories analyzed. The main reason for pleasure among the nurses participating in this study is the positive results obtained from their professional intervention in the health area and wellbeing of the community where they are inserted. The results of the categories and subcategories are presented below.

\section{Resolubility of the nurse's work}

This sense seems quite evident to nurses, as shown below in the participants' speeches.

I feel like my job gives me feedback, so what makes me enjoy it? It's when I can intervene in a patient who has a clinical improvement, has a psychological improvement, has a social improvement... in fact it's the results that make me feel pleasure. When we make a group... when we make a discussion room and see it will change, even if it is a little bit, but it changes something in that person's life. (N1)

A patient arrives with a chronic pain [...], but we can relieve it with acupuncture, it already begins to relieve and it facilitates my work, because we managed to refer him to other things, such as the consultation of a specialist [...]. We are able to solve many things within the unit. (N2)

In primary care, especially in family health, what gives more pleasure is the continuity, when we see the continuity of our work, right? We see it this way... when we have a childcare and see that the child grows healthy and without problems, with no complications in pregnancy, the treatment of tuberculosis was complete [...], it gives pleasure because we see that the work goes on. (N3)
About my assistance, when I feel that what I am doing makes sense and has an answer, has a result [...], I think it makes any worker happy. (N4)

So this is pleasurable for me, it is the return you have, it is you seeing that you can help the other people. In the case of the patient, it is care, it is care, doing the preventive part that is the public health proposal, is not it? (N8)

\section{Interpersonal relationship with the team}

About this aspect, the research subjects agree that the good interpersonal relationship with the team contributes as a facilitator of the work and propitiator of experiences of pleasure:

It is a very good team; we have two doctors, two nurses and a dentist in the building. There are two teams here, but we work well articulated, well integrated, so things get lighter, for example, the reception is divided, it is not overloaded for any professional. (N2)

Here in this unit, we have been here for 14 years and working as a team is very good, it is a very cohesive team. We have a new doctor now, but the doctor who left only left because she retired. The nurse never left, the doctor never left [...], we have been working in a team for a long time, all in the same team, with the same objectives and this is very good. (N3)

The good coexistence with the employees gives me pleasure, makes me happy to have friendship with the other nurses, with the nursing technique, to have a good relationship with the doctors, finally, with the employees of the health post in general. (N4)

Team engagement is a good thing too, when you work with an engaged team, with a harmonious team, it makes the work pleasant. (N8)

This search for conflict management, aimed at the common good, is seen in the speeches of some of the research participants below:

I like my work, many times, there is not even conflict, but some disagreements [...] we do a group therapy work where we have to understand each other, because it is a team, so it makes me very happy. (N3)

When it is a problem of unity we solve it right here in the unit [...] And we talk, everybody, do you understand? It is not perfect, but these things will improve the work over time, it is not in a snap of the fingers, but in right time, with a lot of work, a lot of conversation. (N5)

I have a very good team, all very cooperative, we have our conflicts, but we can solve within the team [...] an excellent work team that I have, so all this brings me great pleasure. (N7)

\section{Therapeutic relationship with the community}

These concepts are so close and intrinsic in the development of care, so nurses sometimes confuse the stages, as seen in the speech of some of the interviewees below: 
What brings me pleasure in the work, first, is the contact with people, the possibility to help these people with my work and my knowledge, to bring a little bit of information. (N7)

Leaving home to go to the PSF, to the community, where you know that you will meet needy people and that you can anyway, even with so many difficulties that we have at work, to help them, to ease their suffering or their concerns, or the pain they feel, anyway, this is pleasant for me. (N8)

\section{Identification/Achievement of the nurse working in the area of nursing and public health}

Analyzing the interviewees' testimonials, is clear that they feel pleasure in being nurses and, even more, because they are inserted in public health:

I really like being a nurse, I [...] graduated without knowing, but I feel identified with my job, and as I currently work in the PSF, I feel with enough autonomy in my function, so I feel pleasure in my work. (N1)

Many people come to work in public health thinking about their salary, I have been working in public health for 18 years, the salary was not so good, but I already came because I liked it and the salary became better and it made my work even better. (N3)

First of all, I like working with public health and within public health, I identified myself with the PSF area and I feel I can achieve some things with the patients with my work, I can take my work for the good of the patients, so I feel so good, very good in PSF doing what I do. (N5)

What gives me pleasure, first is because I like public health, since I graduated eleven years ago, I always worked with public health, so it was an option, I always looked for it because it was what I liked, since college was something that I identified myself with... it was with public health [...] this is pleasant for me. (N8)

We work in a team in which everyone thinks they are responsible, co-responsible for the patient, this is what gives pleasure doing PSF and I love PSF, I'm passionate, it's what I like to do. (N9)

\section{Positive professional return}

In this last category of the theme "Pleasure in the work of nurses at PC," we see great relevance in the study of the theme, since it allows us to understand the ways of organizing the work of nurses in the context of PC.

The subcategories discussed here refer to factors that bring pleasure to the work of the research participants and are seen by them as positive factors and generators of pleasure, motivation and joy in their work environments.

\section{First sub-category: Financial remuneration}

The positive speeches are in relation to the salary. This is because nurses of the municipality under study have struggled for years for salary improvement for their category. They achieved adjustments in the base salary, in addition to the inclusion of the productivity incentive for those who work in the Family Health
Program (PSF) and adjustments linked to the review of the Plan of Jobs, Careers and Wages.

The salary [...] is relatively good. We have an awareness that we have not seen in nursing for a long time, we go on strike, we safe strike, we sustain strikes. (N2)

The issue of remuneration is, in terms of nursing, a good remuneration, let's not say that it is not, [...] is still one of the best. I think everyone wants to work hard and earn money, right? (N3)

Well, I couldn't let it go, in terms of salary it pays well, right? Because if you go to work in a place that you like, but is not paid according to what you do... and we are struggling to improve it, because the Unit, it is the responsibility of the nurse, the nurses are very charged for their work. (N5)

The salary, because when I worked in the traditional unit was a type of salary, after we start working in the family health it gets better, we had an improvement in the salary, and you can acquire more goods, you have more tranquility. (N10)

A satisfactory financial recompense granted to workers is directly linked to pleasure with their labor and brings those experiences of pleasure.

I can say that the salary learn, I think it is fair according to my work, always has an idea of frustration: 'my salary is not goog.' I do not think so. I think learn what is right, I am satisfied with my salary. (N7)

\section{Second subcategory: Recognition of the work of nurses in Primary Care}

The recognition of labor as a source of pleasure was cited by the interviewees, and this is a crucial element for the reduction of suffering and illness in the workplace.

It gives us great pleasure to be recognized for the work that we do, so in the communities that I work, everyone knows me by name, they know what my function, my profession, nobody [...] confuses me with the team doctor! I am the team's nurse; I always make it a point of saying. (N3)

I can say that I have the recognition of my work [...] the professional works satisfied, doing what he likes, what he wants [...], we do have a response from the community to our work [...], we have the recognition of the community and we are aware of it. (N7)

For me it is pleasant, first, because I like very much what I do [...] in PSF and that's it, the return of recognition of the people that you have... for the work you do, for the community and user that you serve, and it gives me pleasure in my work. (N8)

The care of patients, when I feel it was a good care, when I feel that patients are leaving here happy, when I hear compliments about it, too... about my care [...], you have a healthy, nice work environment, where you can laugh, talk and work. (N4)

\section{Third subcategory: Autonomy of nurses in Primary Care}

The autonomy of the PC nurse allows the worker to use creativity, practical intelligence and freedom of expression in the 
work process. Autonomy was not unanimously cited in speeches, but was seen as a category of great importance for this research.

I identify myself with my profession and as I currently work at PSF I feel quite autonomous in my role, so I take pleasure in my work. (N1)

[At work] there is not that immobility that nursing has at the hospitals, depending on the doctor for everything, and sometimes not solving things in primary care, we also have freedom, you have autonomy, you can, [...] for example, at this moment I am with few pregnant women, but I have more children, so we have autonomy to change the calendar, today I will not attend pregnant women, today I will attend children, you have autonomy to solve what to do and this also gives pleasure. (N2)

I also work in an area of hospital care and here in primary care, and the treatment of nurses is very different here in primary care, we have a lot of autonomy, resolubility in attendance, to show our capacity in attendance to the population, this also gives me much satisfaction. The difference between the work I do at night shift and this one, daily, I feel much more fulfilled in primary care. (N10)

Make the program happen, make things have regular assistance, this issue... because in coordination we don't attend directly the users, but we have the means to make the program effective, that's why I work, it's my pleasure. (N11)

\section{DISCUSSION}

The work developed by nurses is considered essential for the consolidation of the assistance in PC. In this perspective, it is important to know the aspects that provide feelings of pleasure in the work of these professionals. This knowledge can contribute to improving the management and quality of attendance in primary care, in addition to contributing to the development of the nurses' potential for their actuation. In this study, resolubility, interpersonal relationships, positive professional feedback, professional recognition, therapeutic relationship with the community, and nurses' autonomy were considered as sources of pleasure at work.

Resolubility is one of the guidelines of the National Policy of Primary Care (Política Nacional de Atenção Básica - PNAB) ${ }^{(1)}$. Therefore, we can see the importance of the results of the work of the PC nurse for the PNAB and for himself, as a subject promoting actions that will bring results. The speeches presented demonstrate that, in addition to the positive results achieved, some talks mixed care with help to the user, because the attachment, the reception and responsibility, together with the resoluteness, compose the structuring of the PC and are often seen by nurses as a single action ${ }^{(1)}$.

Resolubility is seen as an action that generates pleasure ${ }^{(8-10)}$. In the nurses' speech, the idea of longitudinally, typical of the public health area, is implicitly observed, where lasting and slow work is needed to achieve the results, since the establishment of interpersonal bonds is necessary ${ }^{(11)}$. All this responsibility of the professional for the patient's health, in the short and long term, always seeking solutions to their problems, reduces their psychological burden, since it generates a sense of usefulness, brings meaning and finality to the work performed, resulting in pleasure for the worker ${ }^{(12)}$.
In the health team, generally, the nurse occupies a leading position, developing management and care activities. Although the PNAB does not define the professional as coordinator/manager of the team/unit, he assumes this function, due to the historical insertion that the nurse has to be the organizer of the services, being responsible for mediating conflicts, responsible for technical coordination of the nursing team, as well as being the technical reference for the community health agents.

The leadership and management skills of teams are in the nurses' perception of the importance of interpersonal relationships. In the daily work of the health team, the good interpersonal relationship between members is an extremely relevant factor, since working together is necessary for its implementation and directly interferes in the good performance of the professional, with great repercussion on the quality of care provided to the user. In addition to generating a harmonious and cooperative work environment, with a minimum number of conflicts, one of the major factors causing individual and collective stress and suffering.

"Work is not only to produce; it is also to transform oneself and, in the best of cases, it is an opportunity offered to subjectivity to test oneself, even to realize oneself" (13). Thus, it occupies a fundamental role in the lives of people, because it interferes in self-esteem and in interpersonal relationships. Cooperation is another influencing aspect in the integration and organization of work and refers to the willingness that people have to work and overcome together "the contradictions that arise from the nature or essence of work organization"(4), this cooperation requires trust among the team, both the managers and the subordinates.

The importance of a good interpersonal relationship with the team is evident for the well-being of the worker, seen as a facilitator to achieve good results and provide quality assistance to users. Good relationship integrates the multiprofessional team, emerging new forms of work relationship, in a perspective of collective construction ${ }^{(14)}$.

It does not mean that there will never be a conflict between team members, but that the conflict should be directed towards a new construction of relationships, seeking the growth of the team. Confrontation allows a collective discussion, promoting the exchange of grounded arguments, not only technical arguments, considering the subjects and their ethics, aiming at peaceful coexistence and the material transformation of the work process ${ }^{(13)}$.

It is important to manage properly the organizational conflicts in the team, since they are events almost impossible to eradicate. Thus, the development of negotiation strategies and ideas on the subject addressed may work as a driving event of organizational development, promoting the creative process and the reassessment of actions from a new perspective ${ }^{(15-17)}$.

The nurses participating in the research, as managers of the team/unit, try to mediate the conflicts, so that they can bring positive returns to the organization, besides the return of harmony to the work environment. The preferred style of conflict management is collaboration, proposing the maximum integration of the partners seeking the solution of a problem ${ }^{(15)}$.

Conflict mediation collaborates to improve the management and quality of care, since confrontation allows for a collective discussion, promoting the exchange of grounded arguments and not only technical arguments, considering the subjects and 
their ethics ${ }^{(13)}$. Another relevant and extremely important aspect is the existence and maintenance of the therapeutic relationship, because it contributes to the qualification of health care and management at the primary level and includes several stages of health care humanization, such as therapeutic communication, user reception and inclusion, therapeutic bond and care ${ }^{(18)}$.

The therapeutic interpersonal relationship (the caregiver and the person who is cared) brings great positive and encouraging experiences for both, because when they manage to solve the user's problem, they also share pleasure with therapeutic success, generating experiences of learning, reflection and pleasure. The stages of the therapeutic relationship generate pleasure for most of the research participants and, as can be seen in the results of this research, they sometimes place it as a therapeutic bond, sometimes as care provided, precisely because they are often indistinguishable phases of care provision ${ }^{(19)}$.

The construction of professional identity can come from various aspects, such as recognition and personal acknowledgement in the field of social relations. This edification of identity transforms suffering into pleasure, capturing the direct relationship of the subject with society. Work has a determining role in the identity of the subject, being the organizer of routine, social relations and ideas about the future in life ${ }^{(4)}$.

The professional achievement comes from the professional pride, of the experience of professional gratification, of the identification with the job performed and from the importance and usefulness of the work performed. All these aspects are related to experiences of pleasure and satisfaction ${ }^{(16,20)}$. The pleasure that nurses have in caring for people culminates in professional achievement, doing what they like, since nurses who are proud of what they do tend to experience less suffering and more pleasure in their work, as well as greater identification with the organization ${ }^{(21-22)}$.

A study conducted in Kenyan cities in West Africa with primary care workers found that the entire employment relationship of research subjects was by a public tender (which provides job stability), with job and career plan, and it can be a cause of pleasure, since job security is considered a factor of job satisfaction ${ }^{(23)}$.

Working in primary care brings more freedom in the decision making of nurses, both during ambulatory nursing consultations and during home visits and in the management of the unit. This aspect can contribute to the use of creativity and freedom of expression of the professional, who soon fells identified with the work in the public health, giving pleasure in the development of their activities.

It should be noted that the organization of work is characterized by the division of labor, the content of the task, the hierarchical system, the modalities of command, the power relations, among others. Within this universe, we could also consider the remuneration, since it is implicit in the hierarchy, in the power relations and all the burdens or bonuses arising from the relationship of the subject with this organization will be reflected in their experiences of pleasure and/or suffering, in their social environment and in their life ${ }^{(6)}$.

Remuneration is pointed out as a source of pleasure for the worker, contributing to the quality of life. Therefore, it can be a motivating factor, by promoting a sense of well-being, since it improves self-esteem, pride and acknowledgment at work ${ }^{(24-25)}$.
Two factors contribute to the development of human identity, one refers to achievements in the erotic field and love and the other refers to the conquest of identity in the social field, and, within this aspect, recognition for the work done is the main factor for self-realization in the social field. This dynamic of recognition may increase or reduce the risks of development of physical and mental illness related to work $^{(26-27)}$.

It is necessary that people have their work activities valued by two ways: utility and aesthetic judgment. The utility judgment refers to the technical, social or economic relevance of the work, coming from the vertical line, from superiors, subordinates and clients. Aesthetic judgment, which refers to singularity, specificity and mastery in the execution of the work, is given by peers, members of the team or the community ${ }^{(4)}$. It is notorious the great influence of the recognition of the work performed in the lives of the subjects, making them feel less frustrated and less overburdened, despite the deficiencies in the work context ${ }^{(22,28)}$.

The acknowledgment of the work builds its meaning and the suffering caused by the lack of meaning in the work is transformed into pleasure ${ }^{(8)}$. The presence of the recognition of co-workers and users in the generation of pleasure should also be highlighted ${ }^{(9,10)}$.

"In this way, autonomy favors the gain of pleasure at work, based on the transformation of the suffering of not knowing how to something into the pleasure of knowing it"(29). In this conflict we have two forces working: on one side, the worker and his resistance to domination, since his desires and wills can be subjugated and, on the other side, the environment and the work organizations, offering a flexible work organization, allowing the subject to exercise his creative power, or offering a rigid work process, causing suffering.

Nurses should work in primary care independently and interdependently within their team and with other teams, since the population is limited and known within the territory, they should have control over the work process and freedom to exercise it, because it is an environment favorable to the experience of pleasure.

In the Dejourian theory, cooperation is an influential aspect in the integration and complexity of work organization and refers to the willingness of subjects to work together and overcome the contradictions that arise from the nature of work. Thus, satisfaction comes from a rewarding work environment, where factors such as cooperation, interpersonal relationship, communication and autonomy are essential ${ }^{(4,13)}$.

Speeches shows how nurses feel pleasure developing their work with autonomy and freedom, promoting a resolute service and operation in the health units. This is because they do not need to expect attitudes from managers or other professionals, conferring great pleasure in the execution of work, these are necessary mechanisms for maintaining mental equilibrium facing this reality of work ${ }^{(6,29-31)}$.

\section{Study limitations}

The limitations of the study are related to the investigation that occurred in only one municipality, which does not mean that the reality found by nurses is the same in other Brazilian municipalities. Another limitation is the constitution of the sample by nursing professionals from only one of the seven Health Districts of the city studied. 


\section{Contributions to the area of nursing, health or public policy}

The pleasure of work is very pertinent to the people because, in addition to contributing to the quality of the activities provided, it favors health and can be an ally for solve situations that arise in the workplace. Based on this assumption, we can see the importance of this study for the practice of primary care nurses, as it guides them and guide the management regarding to the preservation of factors that sustain the pleasure of these professionals. Therefore, this study is expected to contribute to the promotion of the mental health of nurses working in primary care.

\section{FINAL CONSIDERATIONS}

When evaluating, in this study, the nurses' perception of the experiences of pleasure at work, the results pointed to a positive perception of these themes: resolubility of the nurse's work, interpersonal relationship with the team, therapeutic relationship with the community, identification of the nurse with the work in nursing and in the public health area, and positive professional feedback.

The participants saw several factors as conducive to pleasure in the workplace, configuring the reality of primary care professionals in the studied territory. The data found refer to points that may guide actions that value the optimization of the nurses' work and, consequently, the care provided to the user of the primary care service. By taking care of factors that produce feelings of pleasure at work, it is possible to contribute to a more favorable environment for health, especially the mental health of workers.

\section{FUNDING}

Coordenação de Aperfeiçoamento de Pessoal de Nível Superior (Capes).

\section{ERRATUM}

Article "Feelings of pleasure of nurses working in primary care", with number of DOI: http://dx.doi.org/10.1590/00347167-2018-0518, published in the journal Revista Brasileira de Enfermagem, v72(4): 1036-43, on page 1036:

Where it read:

\section{Sandra Maria de Andrade"}

Rocha GSA, Andrade SM, Silva DMR, Terra MG, Medeiros SEG, Aquino JM. Feelings of pleasure of nurses working in primary care. Rev Bras Enferm. 2019;72(4):1036-43. doi: http://dx.doi.org/10.1590/0034-7167-2018-0518

Read:

\section{Maria Sandra de Andradell}

Rocha GSA, Andrade MS, Silva DMR, Terra MG, Medeiros SEG, Aquino JM. Feelings of pleasure of nurses working in primary care. Rev Bras Enferm. 2019;72(4):1036-43. doi: http://dx.doi.org/10.1590/0034-7167-2018-0518

\section{REFERENCES}

1. Ministério da Saúde (BR). Portaria n 2.436, de 21 de setembro de 2017. Aprova a Política Nacional de Atenção Básica, estabelecendo a revisão de diretrizes para a organização da Atenção Básica, no âmbito do Sistema Único de Saúde (SUS) [Internet]. 2017 [cited 2018 Apr 12]. Available from: http://bvsms.saude.gov.br/bvs/saudelegis/gm/2017/prt2436_22_09_2017.html

2. Acioli S, Kebian LVA, Faria MGA, Ferraccioli P, Correa VAF. Care practices: the role of nurses in primary health care. Rev Enferm UERJ [Internet]. 2014 [cited 2018 Feb 21];22(5):637-42. Available from: http://www.e-publicacoes.uerj.br/index.php/enfermagemuerj/article/ view/12338/12290

3. Silva CCS, Lira ALBC, Feijão AR, Costa IKF, Medeiros SM. Burnout and health technologies in the context of Primary Health Care nursing. EsC Anna Nery. 2017;21(2):1-7. doi: 10.5935/1414-8145.20170031

4. Dejours C. Addendum Da psicopatologia à psicodinâmica do trabalho. In: Lancman S, Sznelwar Ll, editors. Christophe Dejours: da psicopatologia à psicodinâmica do trabalho. 3rd ed. Brasília, Rio de Janeiro: Paralelo 15, Editora Fiocruz; 2011.

5. Campos JF, David HMSL, Souza NVDO. Pleasure and suffering: assessment of intensivist nurses in the perspective of work psychodynamics. Esc Anna Nery. 2014;18(1):90-5. doi: 10.5935/1414-8145.20140013

6. Dejours C. A loucura do trabalho: estudo de psicopatologia do trabalho. 5th ed. São Paulo: Cortez-Oboré; 1992.

7. Bardin L. Análise de conteúdo. Reto LA, Pinheiro A, translators. São Paulo: Edições 70; 2016.

8. Guanaes-Lorenzi C, Pinheiro RL. Is the value of community healthcare agents in Brazil's family health strategy receiving full recognition? Ciênc Saúde Colet. 2016;21(8):2537-46. doi: 10.1590/1413-81232015218.19572015

9. Morais MP, Martins JT, Galdino MJQ, Robazzi MLC, Trevisan GS. [Nurses's work satisfaction in a university hospital]. Rev Enferm UFSM. 2016;6(1):1-9. doi: 10.5902/2179769217766. Portuguese.

10. Santos JLG, Prochnow AG, Silva DC, Silva RM, Leite JL, Erdmann AL. [Pleasure and suffering in nursing management in the hospital context]. Esc Anna Nery. 2013;17(1):97-103. doi: 10.1590/S1414-81452013000100014. Portuguese.

11. Rosane MMS, Beatriz RGOT, Eliane TN, Cynthia BM, Cláudia SV. Longitudinality in child health care in the context of primary care. Rev Enferm UFPE. 2017;11(5):1909-17. doi: 10.5205/reuol.11077-98857-1-SM.1105201721 
Feelings of pleasure of nurses working in primary care

12. Dejours C. O fator humano. Rio de Janeiro: Editora Fundação Getúlio Vargas; 1997.

13. Dejours, C. [Subjectivity, work and action]. Rev Produção [Internet]. 2004 [cited 2014 Nov 17];14(3):27-34. Available from: http://www.scielo. $\mathrm{br} / \mathrm{pdf} / \mathrm{prod} / \mathrm{v} 14 \mathrm{n} 3 / \mathrm{v} 14 \mathrm{n3a03.pdf}$. Portuguese.

14. Silva NS, Esperidião E, Bezerra ALQ, Cavalvante ACG, Souza ACS, Silva KKC. [Perception of nurses about advantages and constraints of their practice in Mental Health services]. Rev Bras Enferm. 2013;66(5):745-52. doi: 10.1590/S0034-71672013000500016. Portuguese.

15. Costa JO, Sousa MNA, Feitosa ANA, Feitosa MO, Assis EV, Custódio PP. [Conflict magement: strategies adopted in a primary health center]. Rev Adm Saúde [Internet]. 2013 [cited 2018 Jun 1];15(61):134-40. Available from: https://www.researchgate.net/publication/286084430 Gestao_de_conflitos_estrategias_adotadas_em_unidade_basica_de_saude.Portuguese.

16. Mendes AM, editor. Psicodinâmica do trabalho: teoria, método e pesquisas. São Paulo: Casa do Psicólogo; 2007.

17. Spagnol CA, Monteiro LAS, Paula CL, Bastos JM, Honorato JAG. [Experiencing conflict situations in the context of nursing: the use of sketch as a teaching-learning strategy]. Esc Anna Nery. 2013;17(1):184-89. doi: 10.1590/S1414-81452013000100026 Portuguese.

18. Ministério da Saúde (BR). Secretaria de Atenção à Saúde. Acolhimento na gestão e o trabalho em saúde. Brasília, DF: Ministério da Saúde; 2016. 32p.

19. Fernández MBE, Luis MAV. Perceptions of the therapeutic relationship from caring professionals in therapeutic communities. Rev Enferm UERJ [Internet]. 2013 [cited 2015 Oct 23];21(3):312-17. Available from: http://www.e-publicacoes.uerj.br/index.php/enfermagemuerj/ article/view/7461/18841

20. Dejours C, Abdoucheli E. Itinerário teórico em psicopatologia do trabalho. In: Dejours C, Abdoucheli E, Jayet C. Psicodinâmica do trabalho: contribuições da escola dejouriana à análise da relação prazer, sofrimento e trabalho. São Paulo: Atlas; 1994. p.119-45.

21. Mariano PP, Carreira L. Pleasure and suffering in the elderly care in long-term care institution: perception of nursing workers. Esc Anna Nery. 2016;20(4):e20160088. doi: 10.5935/1414-8145.20160088

22. Vieira A, Alves M, Monteiro PRR. Garcia FC. Women in nursing teams: organizational identification and experiences of pleasure and suffering. Rev Latino-Am Enfermagem. 2013;21(5):1127-36. doi: 10.1590/S0104-11692013000500016

23. Ojakaa $D$, Olango $S$, Jarvis J. Factors affecting motivation and retention of primary health care workers in three disparate regions in Kenya. Hum Resour Health. 2014;12(33):1-13. doi: 10.1186/1478-4491-12-33.

24. Silva VR, Velasque LS, Tonini T. Job satisfaction in an oncology nursing team. Rev Bras Enferm. 2017;70(5):988-95. doi: 10.1590/0034-7167-2016-0422

25. Prestes FC, Beck CLC, Magnago TSBS, Silva RM, Tavares JP. Working context in a hemodialysis service: evaluation of nursing staff. Text Context Nurs. 2015;24(3):637-45. doi: 10.1590/0104-07072015000220014

26. Dejours C, Molinier P. Le travail comme énigme. Sociologie du Travail [Internet]. 1994 [cited 2015 Oct 23];36(94):35-44. Available from: https://www.persee.fr/doc/sotra_0038-0296_1994_hos_36_1_2147

27. Amorim LKA, Norma VDOS, Ariane SP, Eliane SF, Mariana BS, Angélica CRPV. The nurse's role: recognition and professional appreciation in the user's view. Rev Enferm UFPE. 2017;11(5):1918-25. doi: 10.5205/reuol.11077-98857-1-SM.1105201722

28. Maissiat GS, Lautert L, Pai DD, Tavares JP. Work context, job satisfaction and suffering in primary health care. Rev Gaúch Enferm. 2015;36(2):42-9. doi: 10.1590/1983-1447.2015.02.51128

29. Moraes RD, Vasconcelos ACL, Cunha SCP. [Pleasure in work: the place of autonomy]. Rev Psicol Organ Trab [Internet]. 2012 [cited 2015 Dec 10];12(2):217-27. Available from: http://pepsic.bvsalud.org/pdf/rpot/v12n2/v12n2a07.pdf Portuguese.

30. Davoglio TR, Spagnolo C, Santos BS. [Motivation to remain in the profession: the perception of university teachers]. Psicol Esc Educ. 2017;21(2):175-82. doi: 10.1590/2175-3539/2017/02121099 Portuguese.

31. Azevedo APF, Figueredo VCN. [Pleasure and mental suffering experience at a Center of Psychosocial Care]. Rev Psicol Organ Trab. 2015;15(1):30-42. doi: 10.17652/rpot/2015.1.431 Portuguese. 